\title{
Farm labor, non-farm activities, and poverty alleviation: an ethnography on how upland farmers meet farm demands and sustain household needs
}

\author{
SIMEON C BERNADOS, JR ${ }^{1}$ \\ ${ }^{1}$ Faculty, College of Arts and Science, Cebu Technological University-Main \\ Campus, Cebu City \\ Email Address: simeonjr.bernados@ctu.edu.ph
}

\begin{abstract}
Elimination of poverty in all its form is a challenge that the United Nations must achieve (SDG 1). Poverty is a complex phenomenon and income poverty, most especially in the rural areas, is a paramount concern that needs to be addressed. A total of 12-month ethnographic work was conducted investigating the contribution of non-farm activities (NFAs) of upland farmers in meeting financial requirements for farm operation and household subsistence. Results showed that non-farm activities both livelihood diversification (LD) and crop diversification (CD) were resorted to by upland farmers as means to meet farm requirements and household subsistence. It is recommended that governments through their line agencies shall come up with policies and programs in support to farmers' economic endeavors such as training and extension and technical services to achieve the goal of poverty-free community.
\end{abstract}

Key Words: poverty reduction, livelihood diversification, agricultural diversification, farming practices, upland farmers, rural poverty, sustainable development goal 


\section{Introduction}

Poverty is a social problem that haunts humanity, and its elimination becomes the goals of nations to achieve by 2030. In the past, it was studied in numerous perspectives: first, scholars studied poverty in the context of material affluence, e.g., accumulation of assets, which included among others, accumulation of livestock, size of arable lands, non-farm revenues, farm inputs, cash from non-farm income, and time use (Ellis \& Freeman, 2004; Giurge et al., 2020); secondly, authors put poverty as farmers' inability to adopt modern techniques that would lead to higher productivity and increased income (Peprah et al., 2018; Sobreviñas \& Barrios, 2010); lastly, they attribute poverty as farmers' inability to engage in gainful and profitable non-farm activities that contributed to increased income, offered a better quality of life, and enhanced agricultural productivity (Bagamba et al., 2022; Barrett et al., 2001; Gaillard \& Dervillé, 2022; Haggblade et al., 2010). All these studies suggested that there is a positive correlation between farmers' economic activities and higher income as a way out of poverty, and although there has been cognitive discord along this point, there is a consensus that issues on poverty need to be vigorously pursued (Bezu et al., 2012; Davis et al., 2010).

Even though there is an improvement in the reduction of poverty growth, the number of people living in extreme poverty is on the rise in Sub-Saharan Africa, comprising more than half of the extreme poor in 2015 (Wadhwa, 2018). The World Bank reported that approximately 413 million poor people are living in extreme poverty in Sub-Saharan Africa, which is higher than all other regions of 
the world. If the problem of poverty remained unaddressed and continued to persist, its consequences like access to safe water, education, health care, electricity, and other social and critical services remained elusive and socioeconomic status, gender, ethnicity, and geography determined its access (World Bank, 2019).

With the remaining decade in the fight against poverty, it is very opportune to study specific actions against poverty. In this paper, it is discussed that nonfarm activities (NFAs) are farmers' poverty alleviation strategy. For example, in the paper by Avila-Foucat et al. (2018), farmers undertook diverse livelihood opportunities to improve their chances of survival and well-being. The authors further proved that farmers' involvement in civic activities such as becoming members of farmers' cooperatives, off-farm employment, and other wage-based activities exposed them to opportunities that improved their quality of life (Kassie et al., 2017). However, authors apprised that improvement of well-being brought by productive opportunities was influenced by some indicators e.g. farmers' level of education, access to credit and other financial sources, possession of material wealth, the fluidity in resource mobilization, the expanse of social contacts, proximity from and, availability of market, and the household dependency ratio, which would bring us to the conclusion that farmers' skill need to be upgraded. On the other hand, farmers' cultivation system like intercropping is considered an efficient strategy to improve rural farmers' lives, hence, farmers' traditional practices need support from concerned agencies working on farmers' concerns. However, studies investigating this area of inquiry produced conflicting results, 
bringing into question the factors of investigation, the methodology used, and the circumstances surrounding the subject matter (Kasem \& Thapa, 2011; Kyi \& Doppler, 2011; Michler \& Josephson, 2017).

Non-farm activities diffused the risk against uncertainties such as sickness, calamities, and the effects of seasonal fluctuations leading to crop failure and income loss (Martin \& Lorenzen, 2016). Mango et al (2018) using the case in Malawi, reported on the impact of crop diversification in improving income and securing food in the wake of climate change. However, few papers specific to upland farmers' way of life and farming tradition were published focusing on the strategies of upland farmers to lessen the impact of risk associated with upland farming. Most of the discussion on rural poverty were not specific on the upland rainfed agricultural communities but on rural communities in general. It is along this along this note that this paper would contribute to the stock of literature on the subject matter. This is a very interesting subject matter to pursue for it can invite studies that will describe and analyze upland farmers' actual ways and means in responding to subsistence challenges. This is the gap of research that this paper addresses. When the gap is addressed, it exposes upland farmers' values and other cognitive constructs concerning daily activities and concerns to a much deeper analysis and understanding of their way of life. To be able to address the gap, ethnography was used as the principal approach of inquiry.

The main objective of this paper is to illustrate that NFAs are anti-poverty measures, and farm operations can be sustained, and household needs can be met. To achieve this purpose, the case of an upland rainfed agricultural 
community in Eastern Visayas, Philippines is utilized. This case is unique because the research locale is a rainfed community with its economic activities synchronized with the agricultural cycle which is highly dependent on the forces and events of nature. To prove this concept, this paper is guided by the following questions, to wit: a) in what way do NFAs reduce poverty? b) what are the different NFAs undertaken by upland farmers? In this paper, the author described upland farmers' activities such as, livelihood diversification and agricultural or crop diversification, in meeting their objectives.

This paper has six sections. Section 2 is the discussion on the relationship between diversification and poverty reduction; Section 3 describes the methodologies used in gathering the data; Section 4 discusses upland farmers' strategies to meet their household subsistence needs and farm requirements through the traditional farm practice and NFAs; Section 5 is the discussion on the role of NFAs in the poverty-reduction initiatives; finally is the summary, implications, and conclusion section.

\section{Can resource diversification lead to poverty reduction?}

During economic crisis and uncertainties, diversification of resources and strengthening of capacities become the default response over specialization and become the norm as safeguards against all forms of shocks, be they economic or otherwise (Barrett et al., 2001; Kasem \& Thapa, 2011; Kyi \& Doppler, 2011). One of the justifications used in diversifying resources is the minimization of risk induced by adverse events. For example, in the classic work of Dorsey (1999), citing the case of smallholder coffee growers in Central Kenya, concluded that 
crop diversification like intercropping minimized the risk of crop failure.

Intercropping reduced the spread of plant disease and pest infestation, stabilized production, increased income, and improved efficiency of labor and the use of other resources under conditions of intensification and low technology. In Guatemala, Honduras, and Nicaragua, farmers who practiced biodiverse agroecosystems suffered less damage during extreme climatic events than their conventional monoculture neighbors, thereby, minimizing the risk of income loss (M. A. Altieri \& Nicholls, 2017). These studies emphasized further that diversification decreased vulnerability brought by undesired events, thus minimizing loss through the proper combination of crops (Paul et al., 2016). Crowe and Parker (2008) reported similar results in the area of forestry, DuFour et al. (2015) in fishery, and Aerts et al. (2015) and Beuhler (2006) in water resources management. In this section, two types of systems of diversification in the light of poverty reduction to wit, livelihood diversification and agriculture or crop diversification, are discussed.

Livelihood diversification. Ellis (1998 p.4) defined livelihood diversification (LD) as "the process by which rural families construct a diverse portfolio of activities and social support capabilities for survival to improve their standard of living." In the context of small-farm households, it is the use of nonspecific household assets for non-agriculture activities (Meert et al., 2005) e.g., trade, handicrafts, services, and rents like plow animal rentals (Saha \& Bahal, 2016; Srisopaporn et al., 2015) with the end-goal of increasing income (Makate et al., 2016). Moreover, in some studies, livelihood diversification was viewed 
either as a strategy by wealthy households to accumulate assets (Alobo Loison, 2019; Martin \& Lorenzen, 2016) or as safeguards against economic fluctuations (Fisher et al., 2018) or as a response to crises (Gani et al., 2019; Mentamo \& Geda, 2016). Previous studies demonstrated that LD could benefit farm investment by "employing a variety of nonmarket devices and incomediversification strategies" (Carter, 1997, p. 560) or could pauperize agriculture by withdrawing critical resources and inputs essential for agricultural productivity (Jayne et al., 2003). In some cases, LD has protected the excessive exploitation of natural resources by providing farmers lucrative opportunities outside agriculture-related activities (Kamanga et al., 2009; Nguyen, 2017; Wei et al., 2018) or has pushed hard farmers to consume forest resources, for having not possessed appropriate qualifications for more profitable activities (Kamwi et al., 2018).

In some studies, poverty is measured in terms of assets accumulated from different sources; in this case, asset accumulation becomes the measure of wealth and well-being (Saha \& Bahal, 2016) and were associated with following variables such as household age, environmental consciousness, government regulatory requirements and subsidies, civic engagements, education level, access to credit and other financial resources, perceptions on land tenure, possessions of livestock, and dependency ratio (Avila-Foucat \& RodríguezRobayo, 2018; Kassie et al., 2017; Mentamo \& Geda, 2016; Saha \& Bahal, 2016). To diffuse risk associated with uncertainties, LD is a strategy to reduce vulnerability (Salayo et al., 2012). 
In this paper, it will be demonstrated that livelihood diversification can improve rural farmers' quality of life on two grounds. First, literatures have studied the association between LD and improved quality of life, increased income, food sufficiency, and high agricultural yield and productivity among rural farmers (Gani et al., 2019; Kamwi et al., 2018). Asfaw et al (2019) reported that rural farmers viewed LD activities as a buffer of resources that can be utilized during emergencies and other forms of uncertainties like crop failure or extreme climatic variations. Rural farmers combined farm resources and skills in the performance of LD activities, which revolved around livestock raising, fishing, cropping rotation, and some off-farm activities (Gani et al., 2019). Using the case in Namibia for instance, Kamwi (2018) reported that 95\% of rural farmers engaged in LD activities as anti-poverty measures.

Secondly, LD activities helped reduce poverty levels in the range of $6-9 \%$ (Alobo Loison, 2019) if farmers will be involved in "high return sectors" such as trade or salaried jobs (Gautam \& Andersen, 2016). However, profitability of activities is determined by factors such as the level of education, the distance of work from residence, and household size and dependency ratio (Avila-Foucat \& Rodríguez-Robayo, 2018; Mentamo \& Geda, 2016). In other words, households that were devoid of these qualifications might be excluded from entry to profitable jobs or trade which might affect their well-being. It behooves then that to enhance rural farmers income, it is necessary to upgrade and strengthen their skills to be legible for the requirements of high paying jobs or trade (Maja \& Oluwatayo, 2016). Hence, to improve farmers' economic condition, governments need to 
formulate policies to upgrade skills and qualifications for them to be legible for gainful LD activities (Maja \& Oluwatayo, 2016).

Agricultural diversification. Agricultural or crop diversification is the shift towards high-value crops having great potential for accelerated growth. It is performed either by growing a variety of crops at one time or by growing different crops in different locations at the same time. Furthermore, it is one of the most cost-effective ways of reducing uncertainties like climatic variability, pest infestation, and crop failure (Amare et al., 2018; Feliciano, 2019).

Farmers diversify crops for numerous ends such as to increase income, improve dietary intake, and improve food security (Bommarco et al., 2018; Waha et al., 2018). For example, Nguyen (2017) and Kasem and Thapa (2011) found evidence on the positive effects of diversified farming, especially for small farmers. In one region in China, diversified farms, on a five-year average production, were able to obtain an increased yield from $67.9 \%$ to $97 \%$ (Zhang et al., 2016). Similar trends were observed in South Africa (Michler \& Josephson, 2017) and in some developing countries like Malawi, Nepal, Vietnam, Pakistan, Nicaragua, Indonesia, Albania, and Panama (Kasem \& Thapa, 2011; Kyi \& Doppler, 2011; Pellegrini \& Tasciotti, 2014). As evidenced in these studies, farmers' income was associated with the extent of diversification activities i. e. farmers with low diversification index had low income while those with high diversification index had high income, because in crop diverse farms, rural farmers were cultivating high-value crops (Pellegrini \& Tasciotti, 2014). As for dietary quality, crop diversification improved the diet of rural households (Islam et 
al., 2018), but more than this, these households seldom experienced famine (Waha et al., 2018).

Farmers' utilization of high-value crops (HVCs) helped reduce poverty and risk (Bommarco et al., 2018; Paut et al., 2019). The data from a nationally representative survey in India established that households diversifying toward HVCs were less likely to be poor, and the biggest impact was on the smallholders (Birthal et al., 2015). The authors concluded that for crop diversification to be effective, growers of HVCs need to allocate at least $50 \%$ area to HVCs to escape poverty. In this sense, HVC cultivation assured farmers of food security and diet diversity. Bellon et al (2020) established that crop diversification opens market opportunities for rural households while, at the same time, improving quality of food intake of rural household.

Finally, the decision to diversify is dependent on the farmers' values and priorities which changed through the passage of time (Kidane \& Zegeye, 2018). Farming experience, dependency ratio, the size of plot to cultivate, access to extension services, and access to credit contributed to farmers' decision to diversify. As farmers grew older, production objective might change from profit maximization to risk minimization and farmers may adopt practices which were proven to be effective through time. Dependency ratio implied that households with more dependents were vulnerable to risk and were more willing to diversify; household size determined the number of potential labor participants i.e., the more labor participants, the better for the farm; the size of the plot to cultivate was positively associated with crop diversity; access to extension services 
computed as contact hours with extension agents was significantly associated with diversification; and access to credit significantly influences crop diversification, for it helped farmers in the purchase of high-yielding cropping materials which promised high return, thus increasing household income (Mandal \& Bezbaruah, 2013).

\section{Method}

The data used in this article was the outcome of a 12-month ethnographic work in a Visayan village in the Philippines which studied the local farmers' upland farming practices and their agroecological management. The research locale has 57 household units with rice (Oryza sativa) as the main crop, coconuts (Cocos nucifera), sweetpotato (Ipomoea batatas), and banana (Musa spp.), and some vegetables as secondary crops. The locality has limited flatlands, with an estimated elevation of $25 \mathrm{ft}$ above sea level. Moreover, it is frequented by typhoons with more than 20 typhoons visiting the country annually with 6-9 making a landfall (Strobl, 2019). The household heads were the research participants in the study. The labor types used in agricultural production, farm labor time allocation, crop cultivated, and off-farm activities were the data reported in this article.

Upland farmers' labor pool such as self-labor, unpaid family labor, the collective or communal labor, and hired labor was part of the data used in this paper. Self-labor is the labor type used by the household head; unpaid family labor is the labor type directly contributed by all household members in every 
agricultural task; collective labor, a non-formal reciprocal labor type, is organized as a response against labor bottlenecks; the hired labor is a contract paid labor which is employed for the immediate completion of a task.

Other data sets were the NFAs. Upland farmers have two types of NFAs, to wit: livelihood activities and crop diversification. The former involved incomegenerating activities outside the farm such as livestock-raising, trade, temporary employment as daily wage earners, and marketing of farm produce within and outside the locality; the latter refers to the cultivation of other crops e.g. perennial crops, annual crops, and cash crops in separate plots, aside from the main crop.

Participant-observation (PO) technique was used in data gathering because it maintained the natural setting (Kawulich, 2005) and did not intimidate the research participants nor put them in a very awkward position. The PO established direct contact with the research participants and facilitated the documentation of agricultural activities from field preparation to post-harvest including labor mobilization. However, the shared information was verified with the use other instruments such as checklists, interviews, and other unobtrusive methods to document farm life and other activities. In doing the PO, three phases of observation were followed e.g., activity participation, observation, and interrogation. In activity participation phase, the primary author volunteered as part of the unpaid labor force of the host family to learn the ropes of the trade and establish rapport with the community. Establishment of rapport in this of approach is a conditio sine qua non for a fruitful inquiry. During this process, the primary investigator took the opportunities of engaging farmers in casual 
discussions. The second phase gave the primary researcher the opportunity to observe the how much time is spent in agricultural activities and the allocation of labor used in any agricultural activity. The third phase gave the investigator the opportunity to ask specific information that could give light to the farm practices adopted by the research participants. This was done through personal interviews. Conversations with research participants, which were referred to as personal interviews, were engaged to elicit information on their economic activities specifically on the allocation of labor, marketing of farm products, and decisions on farm operations. These conversations were not audio-recorded, however, and were transcribed immediately from memory after an interview session.

Conversations with the research participants have three important roles in gathering information. First, information not expected by the researcher was discussed during the interview process, as explained in the classic literature (Bagnoli, 2009; Bloom \& Padilla, 1979; Hiller \& DiLuzio, 2004). This information is a reflection of their worldview on the key issues. Furthermore, conversations "allow(ed) interviewers to probe and the interviewees to give narratives of incidents and experiences $\mathrm{x} x \mathrm{x}$ that would result in a more holistic picture of people's understandings" of the phenomenon or experience (Brannen, 2005, p. 182). Second, the conversation is a valuable way of exploring and analyzing people's expectations, goals, emotions, and attitudes. Every conversation instance is unique and reflects the interviewees' desires, perspectives, and views (Hiller \& DiLuzio, 2004). Third, inherent in conversation, it is possible to generate 
a large amount of information covering a wide range of topics (Cassell \& Bishop, 2019).

The Instrument. Customized instruments were generated to facilitate the recording and archival system of the project. Checklists, survey forms, and interview transcript forms were some of the instruments used. Ethnographic journal was kept by the principal investigator where engagement with the research participants was recorded. The principal investigator wrote from memory the transcriptions of interviews immediately after each session.

Where a piece of information needs to be quantified, especially on the time-use of labor according to the different agricultural tasks, estimation technique was used which made research participants recall and estimate the value of such information. This technique has an inherent weakness;

nevertheless, this is the least demanding form of information collection compared to other techniques, e.g., diary method (Bernard \& Killworth, 1993; Keil et al., 2019; Paolisso \& Hames, 2010). Descriptive statistics, e.g., frequency count, mean, and percentage, was used in the analysis.

\section{Results}

In this section, two research questions would be answered: a) in what way do NFAs reduce poverty? and b) what are the different NFAs undertaken by upland farmers as a strategy to finance agricultural production and maintain household subsistence? 
Final Version

\section{NFAs as poverty reduction strategy}

Labor use, agricultural tasks, and time use. Assessment of the upland farming practice is essential in the investigation of upland farmers' NFAs whether these NFAs are compatible activities with the existing farm practices of upland farmers. Authors assumed in this article that NFAs are part of upland farmers' traditional farming practices and were used as an additional financial resource for farm operations and household subsistence. To this end, this paper would explain that the NFAs are compatible with the timing of the agricultural tasks.

This is shown in Table 1.

Table 1. Percentage of change of average labor time input (man/hours) expended by upland households in an agricultural cropping cycle

\begin{tabular}{|c|c|c|c|c|c|c|}
\hline \multirow[t]{2}{*}{ Labor Types } & \multicolumn{6}{|c|}{ Field Tasks } \\
\hline & $* \mathrm{FP}$ & *PL & $* H R$ & $* \mathrm{MA}$ & $* \mathrm{HA}$ & $\begin{array}{l}\text { Total } \\
\text { mean } \\
\text { hours }\end{array}$ \\
\hline Self & 33.70 & 1.37 & 11.65 & 2.50 & 4.13 & 53.35 \\
\hline Family & 3.68 & 0.39 & 5.75 & 1.64 & 7.71 & 19.17 \\
\hline Cooperative & 1.21 & 1.84 & 0.56 & 0.13 & 0.84 & 4.58 \\
\hline Hired & 4.43 & 5.60 & 2.14 & 0.07 & 6.23 & 18.47 \\
\hline Total Mean & 43.02 & 8.90 & 20.10 & 4.34 & 18.91 & 95.57 \\
\hline
\end{tabular}

Legend:

*FP= field preparation/paddy repair

*PL $=$ planting/re-planting/transplanting

$* \mathrm{HR}=$ weeding/pest management

*MA $=$ fertilizer application

$* \mathrm{HA}=$ harvesting 
The complementing nature of the NFAs with the agricultural undertakings of the upland farmers is reflected as the allocation and mobilization of the labor force used in the different agricultural tasks. Data showed that upland farmers spent an average of 95.57 hours per cropping cycle or 191.14 hours for two croppings in a year. This relatively low time input, compared to the industrial time use of at least 40 hours per week ( 2080 hours annually), is exacerbated with the practice of fallow period, not to mention the slack period in between agricultural tasks. It was during the fallow period that no crops were planted on the land, allowing the land to rest so that the land can "gain back" its fertility. It is during the fallow period and slack period that upland farmers undertook various NFAs.

Table 1 further showed the application of labor types in the different field tasks or agricultural tasks, namely the unpaid family labor, self-labor, collaborative/exchange labor, and the hired or contract labor. Self-labor is a personal labor used by the upland farmers themselves; unpaid family labor is the labor contribution of every abled member of the household; collective labor type is the labor contribution of members in a labor exchange group which every member has to reciprocate whenever assistance is called; hired labor types are individuals who are paid to perform some tasks requiring immediate action.

Moreover, in an agricultural cycle, five tasks were involved, namely: field preparation/ paddy repair, planting/ replanting, weeding/ harrowing/ pest control, fertilizer application/ manuring, and harvesting. In every task, a corresponding labor type is mobilized by upland farmers. 
Data showed that in field preparation or paddy repair, weeding/ harrowing/ pest control, and manuring/ fertilizer application, upland farmers relied on selflabor (53.35 hrs), followed by the unpaid family labor ( $19.17 \mathrm{hrs})$, the hired or contract labor (18.47 hours), and the collective or exchange labor (4.58 hours). During planting and harvesting periods, upland farmers used hired/ contract labor as evidenced in their time use of 5.60 hours and 6.23 hours, respectively.

As observed, upland rice farmers adopted synchronized farming in order to be "on time" and "stay on time". Hence, to "stay on time" entails repercussions on the farming practice, thus, an additional labor force is required to be able to "stay on time". In this connection, the use of self-labor, contract labor, collective or exchange labor, and the unpaid family labor types are resorted to in order to "be on time" and as a response to probable labor bottlenecks brought about by labor scarcity.

Of all the agricultural tasks, field preparation and paddy repair took most of the upland farmers' time with the use of hired/contract and unpaid family labor types because rice paddies, most of the time, got destroyed during typhoons. In general, upland agriculture is a personal and family undertaking as evidenced in the reliance on self and unpaid family labor types with 53.35 hours and 19.17 hours, respectively. All other labor types were support labor types which made upland farmers "to be on schedule" in the conduct of farm activities. 


\section{Different NFAs undertaken by upland farmers as poverty alleviation tool}

Diversification activities of upland farmers. With a relatively low time

input as compared to normal annual working hours in the industrial sector, upland farmers have time for income-generating activities to support farm operations. While the land is fallowed or during slack period, livelihood diversification activities provide additional cash for both farm operations and household subsistence. Upland farmers undertook livestock-raising, fishing, carpentry, trading, and cultivation of various crops as their income-generating activities (Table 2).

Livelihood activities. Table 2 showed the various livelihood activities undertaken by upland rice farmers. Majority of upland farmers undertook livestock raising (68\%). Several chickens, cattle, pigs, and goats were the common livestock raised by upland farmers which were sold in the nearby market or self-consumed. Livestock-raising played an important component in every upland household, for domestic animals could be a good source of cash and protein for the family.

Beside livestock-raising, some upland farmers sought temporary employment doing carpentry work in a nearby locality (11\%) as semi-skilled workers. As semi-skilled workers, their wages could not be higher than their skilled counterparts because of the lack of necessary skills and training required for a highly technical and complex task. Similar results were reported in previous studies (Barrett et al., 2001; Ellis \& Freeman, 2004; Meert et al., 2005). 
Table 2. Economic profile of the upland farm household other than rice farming

\begin{tabular}{|c|c|c|}
\hline Variable & $f$ & $\%$ \\
\hline \multicolumn{3}{|l|}{ Livelihood options other than rice farming } \\
\hline Livestock-raising & 50 & 88 \\
\hline Vegetable raising & 22 & 39 \\
\hline Wine (tuba) gathering & 22 & 39 \\
\hline Carpentry & 8 & 14 \\
\hline Fishing & 8 & 14 \\
\hline Selling & 6 & 11 \\
\hline Lumbering & 1 & 2 \\
\hline \multicolumn{3}{|l|}{ Livelihood options combinations } \\
\hline Fishing-vegetable raising & 13 & 23 \\
\hline Fishing-livestock-vegetable raising & 3 & 5 \\
\hline Fishing-livestock raising & 1 & 2 \\
\hline Livestock-carpentry & 1 & 2 \\
\hline Livestock-vegetable raising & 1 & 2 \\
\hline Lumbering-vegetable raising & 1 & 2 \\
\hline Selling-vegetable raising & 1 & 2 \\
\hline Vegetable raising-tuba gathering & 1 & 2 \\
\hline Fishing-selling-livestock raising & 1 & 2 \\
\hline Livestock raising-vegetable-carpentry & 1 & 2 \\
\hline \multicolumn{3}{|l|}{ Vegetation cultivated other than rice } \\
\hline Banana-coconut & 10 & 18 \\
\hline Banana-coconut-legumes & 6 & 11 \\
\hline Coconut-legumes & 4 & 7 \\
\hline Banana-coconut-rootcrops & 3 & 5 \\
\hline Banana-coconut-legumes-fruit trees & 3 & 5 \\
\hline Banana-legumes & 2 & 4 \\
\hline Banana-rootcrops & 2 & 4 \\
\hline Coconut-rootcrops & 2 & 4 \\
\hline Coconut-legumes-corn-rootcrops & 2 & 4 \\
\hline Banana-coconut-legumes-fruit trees- & 2 & 4 \\
\hline rootcrops & 1 & 2 \\
\hline Banana- cacao & 1 & 2 \\
\hline Legumes-corn-rootcrops & 1 & 2 \\
\hline Coconut-abaca & 1 & 2 \\
\hline Banana-legumes-corn-rootcrops & 1 & 2 \\
\hline Banana-coconut-legumes-fruit trees-buri & 1 & 2 \\
\hline Coconut-legumes-abaca & 1 & 2 \\
\hline Banana-coconut-abaca & 1 & 2 \\
\hline Coconut-legumes-fruit trees & 1 & 2 \\
\hline $\begin{array}{l}\text { Coconut-legumes-fruit trees-rootcrops-abaca } \\
\text { Banana-coconut-fruit trees }\end{array}$ & 1 & 2 \\
\hline
\end{tabular}


Upland farmers undertook small-scale fishing which were mostly done during the slack period or fallow period $(11 \%)$. It is a source for cash. Upland farmers sold a portion of the catch of the day in the nearby market and used the rest of the catch for household consumption.

In some cases, some upland farmers undertook livelihood activities with another member of the household to augment potential income. For instance, in fishing-vegetable gardening (54\%), fishing was done by upland farmers while vegetable gardening was done by the household member. Like all others, some of the produce was converted to cash and the rest for household consumption.

Crop diversification. Upland farmers cultivated other crops either as an intercrop or serial crop. Usually, upland farmers undertook perennial-cash crop combination (Table 2). They maintained perennial crops e.g. coconuts and banana (Musa spp.) in their farms. These crops are not labor intensive, hence, upland farmers used the self-labor or the unpaid family labor to maintain these crops. Moreover, these two crops were considered as high-value crops (Espino \& Atienza, 2001).

The most common perennial crop cultivated by upland farmers was the coconut. It is intercropped with one or more cash crops like banana, vegetable, and mungbean, among others. Known for the diversity of its use, coconuts played a significant role in upland farmers' household. The fruit, husk, water, shell, and kernel are all used and can be transformed into economically valued goods. Additionally, the fronds and the stem are also used in various industries. This unique feature of the coconut palm gives coconut farmers incentives for 
economic sustainability even when there is a demand decline for a particular item (Suriya, 2016).

The banana (Musa spp.) is a perennial plant that replaces itself and an important cash crop in the Philippines (Banana Consumption Per Capita in Philippines, 2020). At the micro level, banana is an important crop at the household level with consideration of its demand at the macro level. It is an essential source of income for many households as well as a source of nutrition (Salvacion, 2019). On a national level, the Philippines exported 1.8 million metric tons of fresh bananas in 2017 amounting to almost USD 1.1 billion. In 2013, the Philippines consumed $53 \mathrm{~kg}$ per capita (Banana Consumption Per Capita in Philippines, 2020).

\section{Discussion}

To combat the effects of poverty, proper allocation and use of resources is a sound management strategy. In this case, farm labor and the various NFAs were the available resources of upland farmers. Upland farmers have two sets of NFAs: livelihood diversification activities and crop diversification schemes. For the former, upland farmers embarked on livestock-raising, temporary employment, fishing, trade, and services. For the latter, they took on intercropping with the use of perennial crops, annual crops and high-value crops (HVCs) as cash crops.

Increasing income begins by minimizing overhead expenditures through the use of the self-labor, unpaid family labor, and the collective or communal labor. The utilization of these labor types minimized financial liabilities like 
payment of rents and wages, and the amount saved was appropriated for the purchase of farm implements and other inputs required for the farm operations and other purposes. This practice of cost-cutting by identifying areas that would entail high cost has been discussed in previous research. Hussain and Ahmad (2018) and Chan (2012) reported that identifying factors that would provide a better understanding of overheads could lead to sound financial management. In the present case, farmers adopted the synchronized farming system of which labor shortage is a possibility. To anticipate labor shortages that could delay in the implementation of agricultural activities, upland farmers resorted to hire labor to speed up the completion of a task e.g., paddy repair or harvesting. To cut cost, upland farmers strategized the mobilization of their available labor force such as the self-labor, unpaid family labor, and the collective or communal labor. As reported by previous studies, hired labor was used for exhaustive tasks or tasks requiring immediate action e.g., field preparation/ paddy repair, planting, and harvesting tasks. Similar findings were reported in earlier studies (Haider et al., 2018; Pretty et al., 2011; Stone et al., 1990; Waha et al., 2018).

Secondly, upland farmers considered off-farm employment as a buffer capital to sustain the upland agricultural enterprise. Off-farm livelihood opportunities assured farmers of additional cash inflow. While cultivation of the main crop was done during the farming season, livelihood activities were performed during off-farm season, field fallow, and slack period. In the scheduling of income-generating activities, upland farmers were to blend their on-farm activities with the off-farm activities like the case of Timorese farmers as 
reported by Fisher et al (2018). The authors explained that farmers' NFAs complemented farming activities arguing that the seasonal integration of manganese mining and farming was a natural blend of complementary activities "with farming providing household food requirements and some income, and mining providing income security when crops failed" (Fisher et al., 2018, p. 9).

Thirdly, crop diversification and commercialization of the produce were other profitable activities that contributed to increased income. Crop diversification provides upland farmers with the opportunity to select a particular crop which has commercial values, such as coconuts, banana, vegetable like legumes, that could promise high return. In the present case, two important crops e.g. coconuts and bananas were cultivated by farmers in combination with other crops such as vegetables, legumes, and other crops. Both crops were classified as perennial crops and were intercropped with other HVCs. In conjunction with this, literatures discussing on crop diversification reported that households venturing into HVCs were less likely to remain poor (Bellon et al., 2020; Birthal et al., 2015; Pellegrini \& Tasciotti, 2014) and have many opportunities to vary food consumption (M. Altieri, 2018; Chandrakant et al., 2016; Mustafa et al., 2019).

Upland farmers' decision to diversify is a reflection of their values and priorities which were acted upon through the utilization of their resources e.g. both human and non-human and the apportionment of task. Attempts to understand farmers' values and aspirations require the understanding of their cultural milieu which is concretized in their practices. Paramount of their concern is the welfare of the household, hence, they cannot afford to put their households 
at risk by adopting farm methods that they are not familiar with. With the many uncertainties associated with agriculture, it is expected that upland farmers would continue their farming tradition. To hold on to practices that they are familiar with is for them the most rational action to undertake (De Buck et al., 2001; Gladwin, 1980; Greiner et al., 2009). It is for this reason that upland farming is characterized by tradition with cultivators' values, needs, and rationality embedded in their farming practice (Casiño \& Casiño, 1976; Eder, 2003, 2010) which would become the basis in the perpetuation of their practices.

\section{Conclusion, Insights, and Recommendation}

Upland farmers' farm management to beat economic challenges is diverse, which includes livelihood and crop diversification. The role of labor types played a significant role in upland agriculture, for it determined the feasibility of undertaking NFAs. If labor bottlenecks cannot be addressed, crop failure is possible which upland farmers cannot afford to occur. Hence, upland farmers' management of land, labor, crops, and capital is a result of a complex interaction among several interdependent components of which cultivators have access --both human and non-human --- to maximize the attainment of goals. In this manner, upland farmers have control of the many alternatives at their disposal, which minimizes the risk. In the overall, agricultural management of upland farmers is aimed towards the implementation of agricultural goals of households i.e. increased income and the minimization of risks associated with upland agriculture. 
In the present discussion, the practice of participating in the many NFAs has proven to improve economic conditions of upland farmers. Like any other studies discussing the many positive contributions of diversification activities to farmers' lives, encouraging farmers to undertake diversification activities need governments' support. Since poverty is mostly concentrated in rural areas, the rural poor, especially the upland households, are vulnerable to all forms of economic shocks. Hence, it is recommended that policies and intervention programs aimed at improving stakeholders' lives need to be designed and vigorously implemented to achieve a poverty-free community.

\section{Limitation of the Study}

There are some limitations that need to be recognized in the current study. First, the study was limited only to a specific locality, and the chance of having similar situations is possible which may affect the generalizability of the findings. Although the study aimed to investigate the practices of upland farming communities in their struggles against poverty, there is a need of cross-cultural comparison to determine the different farming practices as anti-poverty strategies. To obtain a picture of upland households' activities to meet their economic obligations, other data from other upland locality need to be investigated. Secondly, income of households was not considered in this paper for research participants considered it invasive of their privacy of which the researcher has to respect. Thirdly, this paper relied heavily on the self-report of upland farmers of which the data need to be compared with official reports of both government and non-governmental agencies. 


\section{Ethical Considerations}

The study was given approval by the Research and Development Council of the University. Prior informed consent was solicited individually from the research participants not only during interview sessions but also on the actual work conducted on the research participants' farm.

\section{Conflict of Interest}

None declared.

\section{References:}

Aerts, J. C., Botzen, W. W., \& Werners, S. E. (2015). Portfolios of adaptation investments in water management. Mitigation and Adaptation Strategies for Global Change, 20(8), 1247-1265.

Alobo Loison, S. (2019). Household livelihood diversification and gender: Panel evidence from rural Kenya. Journal of Rural Studies, 69, 156-172. https://doi.org/10.1016/j.jrurstud.2019.03.001

Altieri, M. (2018). Agroecology:The Science of Sustainable Agriculture (Vol. 448). Taylor \& Francis.

Altieri, M. A., \& Nicholls, C. I. (2017). The adaptation and mitigation potential of traditional agriculture in a changing climate. Climatic Change, 140(1), 3345. https://doi.org/10.1007/s10584-013-0909-y 
Amare, M., Mavrotas, G., \& Edeh, H. (2018). Farmers' Crop Choice Decisions: Trends and Determinants in Nigeria and Uganda. International Food Policy Research Institute. www.ifpri.org

Asfaw, S., Scognamillo, A., Caprera, G. D., Sitko, N., \& Ignaciuk, A. (2019). Heterogeneous impact of livelihood diversification on household welfare: Cross-country evidence from Sub-Saharan Africa. World Development, 117, 278-295. https://doi.org/10.1016/j.worlddev.2019.01.017

Avila-Foucat, V. S., \& Rodríguez-Robayo, K. J. (2018). Determinants of livelihood diversification: The case wildlife tourism in four coastal communities in Oaxaca, Mexico. Tourism Management, 69(June), 223-231. https://doi.org/10.1016/j.tourman.2018.06.021

Bagamba, F., Ruben, R., \& Kuyvenhoven, A. (2022). Determinants of Smallholder Farmer Labor Allocation Decisions in Uganda. Journal of African Development, 23(1), 1-34.

Bagnoli, A. (2009). Beyond the standard interview: The use of graphic elicitation and arts-based methods. Qualitative Research, 9(5), 547-570. https://doi.org/10.1177/1468794109343625

Banana Consumption Per Capita in Philippines. (2020).

https://www.helgilibrary.com/indicators/banana-consumption-percapita/philippines

Barrett, C. B., Reardon, T., \& Webb, P. (2001). Nonfarm income diversification and household livelihood strategies in rural Africa: Concepts, dynamics, and policy implications. Food Policy, 26(4), 315-331. 
Bellon, M. R., Kotu, B. H., Azzarri, C., \& Caracciolo, F. (2020). To diversify or not to diversify, that is the question. Pursuing agricultural development for smallholder farmers in marginal areas of Ghana. World Development, 125, 104682. https://doi.org/10.1016/j.worlddev.2019.104682

Bernard, H. R., \& Killworth, P. D. (1993). Sampling in time allocation research. Ethnology, 32(2), 207-215.

Beuhler, M. (2006). Application of modern financial portfolio theory to water resource portfolios. Water Science and Technology: Water Supply, 6(5), $35-41$.

Bezu, S., Barrett, C. B., \& Holden, S. T. (2012). Does the nonfarm economy offer pathways for upward mobility? Evidence from a panel data study in Ethiopia. World Development, 40(8), 1634-1646.

Birthal, P. S., Roy, D., \& Negi, D. S. (2015). Assessing the impact of crop diversification on farm poverty in India. World Development, 72, 70-92. https://doi.org/10.1016/j.worlddev.2015.02.015

Bloom, D., \& Padilla, A. M. (1979). A peer interviewer model in conducting surveys among Mexican-American youth. Journal of Community Psychology., 7(2), 136-192.

Bommarco, R., Vico, G., \& Hallin, S. (2018). Exploiting ecosystem services in agriculture for increased food security. Global Food Security, 17, 57-63. https://doi.org/10.1016/j.gfs.2018.04.001

Brannen, J. (2005). Mixing methods: The entry of qualitative and quantitative approaches into the research process. International Journal of Social 
Research Methodology, 8(3), 173-184.

https://doi.org/10.1080/13645570500154642

Carter, M. R. (1997). Environment, technology, and the social articulation of risk in West African agriculture. Economic Development and Cultural Change, 45(3), 557-590.

Casiño, E., \& Casiño, E. S. (1976). The Jama Mapun: A changing Samal society in the southern Philippines. Cellar Book Shop.

Cassell, C., \& Bishop, V. (2019). Qualitative data analysis: Exploring themes, metaphors and stories. European Management Review, 16(1), 195-207. https://doi.org/10.1111/emre.12176

Chan, C. T. W. (2012). The principal factors affecting construction project overhead expenses: An exploratory factor analysis approach. Construction Management and Economics, 30(10), 903-914. https://doi.org/10.1080/01446193.2012.717706

Chandrakant, A., Subhash, C., Firoz, H., \& Kumar Rai, A. (2016). Multi storied cropping system in horticulture-a sustainable land use approach. International Journal of Agriculture Sciences, 8(55), 975-3710.

Crowe, K. A., \& Parker, W. H. (2008). Using portfolio theory to guide reforestation and restoration under climate change scenarios. Climatic Change, 89(34), 355-370.

Davis, B., Winters, P., Carletto, G., Covarrubias, K., Quiñones, E. J., Zezza, A., Stamoulis, K., Azzarri, C., \& DiGiuseppe, S. (2010). A cross-country 
comparison of rural income generating activities. World Development, 38(1), 48-63.

De Buck, A. J., Van Rijn, I., Roling, N. G., \& Wossink, G. A. A. (2001). Farmers' reasons for changing or not changing to more sustainable practices: An exploratory study of arable farming in the Netherlands. The Journal of Agricultural Education and Extension, 7(3), 153-166.

Dorsey, B. (1999). Agricultural intensification, diversification, and commercial production among smallholder coffee growers in central Kenya. Economic Geography, 75(2), 178-195.

DuFour, M. R., May, C. J., Roseman, E. F., Ludsin, S. A., Vandergoot, C. S., Pritt, J. J., Fraker, M. E., Davis, J. J., Tyson, J. T., \& Miner, J. G. (2015). Portfolio theory as a management tool to guide conservation and restoration of multi-stock fish populations. Ecosphere, 6(12), 1-21.

Eder, J. F. (2003). Of fishers and farmers: Ethnicity and resource use in coastal Palawan. Philippine Quarterly of Culture and Society, 31(3), 207-225.

Eder, J. F. (2010). Ethnic differences, Islamic consciousness, and Muslim social integration in the Philippines. Journal of Muslim Minority Affairs, 30(3), 317-332.

Ellis, F. (1998). Household strategies and rural livelihood diversification. The Journal of Development Studies, 35(1), 1-38.

Ellis, F., \& Freeman, H. A. (2004). Rural livelihoods and poverty reduction strategies in four African countries. Journal of Development Studies, 40(4), 1-30. 
Espino, R. R., \& Atienza, C. (2001). Crop diversification in the Philippines. In Crop Diversification in Asia-Pacific Region (pp. 95-111). FAO. http://www.fao.org/3/x6906e/x6906e0a.htm

Feliciano, D. (2019). A review on the contribution of crop diversification to Sustainable Development Goal 1 "No poverty" in different world regions. Sustainable Development, 27(4), 795-808. https://doi.org/10.1002/sd.1923

Fisher, R., Ling, H., Natonis, R., Hobgen, S., Kaho, N. R., Mudita, W., Markus, J., Bunga, W., \& Nampa, W. (2018). Artisanal and small-scale mining and rural livelihood diversification: The case of manganese extraction in West Timor, Indonesia. Extractive Industries and Society, June, 1-12. https://doi.org/10.1016/j.exis.2018.08.004

Gaillard, C., \& Dervillé, M. (2022). Dairy farming, cooperatives and livelihoods: Lessons learned from six indian villages. Journal of Asian Economics, 78, 101422.

Gani, B. S., Olayemi, J. K., \& Inoni, O. E. (2019). Livelihood diversification strategies and food insecurity status of rural farming households in NorthEastern Nigeria. Economics of Agriculture, 66(1), 281-295. https://doi.org/10.5937/ekoPolj1901281G

Gautam, Y., \& Andersen, P. (2016). Rural livelihood diversification and household well-being: Insights from Humla, Nepal. Journal of Rural Studies, 44, 239-249. https://doi.org/10.1016/j.jurstud.2016.02.001 
Giurge, L. M., Whillans, A. V., \& West, C. (2020). Why time poverty matters for individuals, organisations and nations. Nature Human Behaviour, 4(10), 993-1003.

Gladwin, C. H. (1980). A theory of real-life choice: Applications to agricultural decisions. Agricultural Decision Making: Anthropological Contributions to Rural Development, 45-85.

Greiner, R., Patterson, L., \& Miller, O. (2009). Motivations, risk perceptions and adoption of conservation practices by farmers. Agricultural Systems, 99(23), 86-104.

Haggblade, S., Hazell, P., \& Reardon, T. (2010). The rural non-farm economy: Prospects for growth and poverty reduction. World Development, 38(10), $1429-1441$.

Haider, H., Smale, M., \& Theriault, V. (2018). Intensification and intrahousehold decisions: Fertilizer adoption in Burkina Faso. World Development, 105, 310-320. https://doi.org/10.1016/j.worlddev.2017.11.012

Hiller, H. H., \& DiLuzio, L. (2004). The interviewee and the research interview: Analysing a neglected dimension in research. Canadian Review of Sociology/Revue Canadienne de Sociologie, 41(1), 1-26.

Hussain, S. Z., \& Ahmad, N. (2018). Minimizing broadcast expenses in clustered ad-hoc networks. Journal of King Saud University - Computer and Information Sciences, 30(1), 67-79.

https://doi.org/10.1016/j.jksuci.2016.05.001 
Jayne, T. S., Yamano, T., Weber, M. T., Tschirley, D., Benfica, R., Chapoto, A., \& Zulu, B. (2003). Smallholder income and land distribution in Africa: Implications for poverty reduction strategies. Food Policy, 28(3), 253-275. https://doi.org/10.1016/S0306-9192(03)00046-0

Kamanga, P., Vedeld, P., \& Sjaastad, E. (2009). Forest incomes and rural livelihoods in Chiradzulu District, Malawi. Ecological Economics, 68(3), 613-624. https://doi.org/10.1016/j.ecolecon.2008.08.018

Kamwi, J. M., Chirwa, P. W. C., Graz, F. P., Manda, S. O. M., Mosimane, A. W., \& Kätsch, C. (2018). Livelihood activities and skills in rural areas of the Zambezi region, Namibia: Implications for policy and poverty reduction. African Journal of Food, Agriculture, Nutrition and Development, 18(1). https://www.ajol.info/index.php/ajfand/article/view/169967

Kasem, S., \& Thapa, G. B. (2011). Crop diversification in Thailand: Status, determinants, and effects on income and use of inputs. Land Use Policy, 28(3), 618-628. https://doi.org/10.1016/j.landusepol.2010.12.001

Kassie, G. W., Kim, S., \& Fellizar, F. P. (2017). Determinant factors of livelihood diversification: Evidence from Ethiopia. Cogent Social Sciences, 3(1), 1369490. https://doi.org/10.1080/23311886.2017.1369490

Kawulich, B. B. (2005). Participant observation as a data collection method. Forum Qualitative Sozialforschung / Forum: Qualitative Social Research, 6(2). https://doi.org/10.17169/fqs-6.2.466

Keil, A., Mitra, A., Srivastava, A. K., \& McDonald, A. (2019). Social inclusion increases with time for zero-tillage wheat in the Eastern Indo-Gangetic 
Plains. World Development, 123, 104582.

https://doi.org/10.1016/j.worlddev.2019.06.006

Kidane, M. S., \& Zegeye, E. W. (2018). Crop diversification and productivity in semiarid and sub-humid maize-legume production systems of Ethiopia. Agroecology and Sustainable Food Systems, 42(10), 1106-1127. https://doi.org/10.1080/21683565.2018.1505679

Kyi, T., \& Doppler, W. (2011). Impact of crop diversification on income generation of beneficiaries under rice based irrigated farming system of Myanmar. Asia-Pacific Journal of Rural Development, 21(1).

Maja, T., \& Oluwatayo, I. (2016). Livelihood diversification and poverty among rural households in the Capricorn District, Limpopo, South Africa. AgEcon Search, 44, 239-249. https://doi.org/10.22004/ag.econ.284752

Makate, C., Wang, R., Makate, M., \& Mango, N. (2016). Crop diversification and livelihoods of smallholder farmers in Zimbabwe: Adaptive management for environmental change. SpringerPlus, 5(1135), 1-18.

https://doi.org/10.1186/s40064-016-2802-4

Mandal, R., \& Bezbaruah, M. (2013). Diversification of cropping pattern: Its determinants and role in flood affected agriculture of Assam Plains. Indian Journal of Agricultural Economics, 68(2), 170-181.

Mango, N., Makate, C., Mapemba, L., \& Sopo, M. (2018). The role of crop diversification in improving household food security in central Malawi. Agriculture \& Food Security, 7(1), 7. https://doi.org/10.1186/s40066-0180160-x 
Martin, S. M., \& Lorenzen, K. (2016). Livelihood diversification in rural laos. World Development, 83, 231-243. https://doi.org/10.1016/j.worlddev.2016.01.018

Meert, H., Van Huylenbroeck, G., Vernimmen, T., Bourgeois, M., \& Van Hecke, E. (2005). Farm household survival strategies and diversification on marginal farms. Journal of Rural Studies, 21(1), 81-97.

Mentamo, M., \& Geda, N. R. (2016). Livelihood diversification under severe food insecurity scenario among smallholder farmers in Kadida Gamela District, Southern Ethiopia. Kontakt, 18(4), e258-e264.

https://doi.org/10.1016/j.kontakt.2016.09.003

Michler, J. D., \& Josephson, A. L. (2017). To specialize or diversify: Agricultural diversity and poverty dynamics in Ethiopia. World Development, 89, 214226. https://doi.org/10.1016/j.worlddev.2016.08.011

Mustafa, M. A., Mayes, S., \& Massawe, F. (2019). Crop diversification through a wider use of underutilised crops: A strategy to ensure food and nutrition security in the face of climate change. In A. Sarkar, S. R. Sensarma, \& G. W. vanLoon (Eds.), Sustainable Solutions for Food Security: Combating Climate Change by Adaptation (pp. 125-149). Springer International Publishing. https://doi.org/10.1007/978-3-319-77878-5_7

Nguyen, H. Q. (2017). Analyzing the economies of crop diversification in rural Vietnam using an input distance function. Agricultural Systems, 153, 148156. https://doi.org/10.1016/j.agsy.2017.01.024 
Paolisso, M., \& Hames, R. (2010). Time diary versus instantaneous sampling: A comparison of two behavioral research methods. Field Methods, 22(4), 357-377.

Paul, C. J., Weinthal, E. S., Bellemare, M. F., \& Jeuland, M. A. (2016). Social capital, trust, and adaptation to climate change: Evidence from rural Ethiopia. Global Environmental Change, 36, 124-138. https://doi.org/10.1016/j.gloenvcha.2015.12.003

Pellegrini, L., \& Tasciotti, L. (2014). Crop diversification, dietary diversity and agricultural income: Empirical evidence from eight developing countries. Canadian Journal of Development Studies / Revue Canadienne d'études Du Développement, 35(2), 211-227. https://doi.org/10.1080/02255189.2014.898580

Peprah, P., Amoako, J., Adjei, P. O.-W., \& Abalo, E. M. (2018). The syncline and anticline nature of poverty among farmers: Case of cashew farmers in the Jaman South District of Ghana. Journal of Poverty, 22(4), 355-377. https://doi.org/10.1080/10875549.2017.1419534

Pretty, J., Toulmin, C., \& Williams, S. (2011). Sustainable intensification in African agriculture. International Journal of Agricultural Sustainability, 9(1), 5-24. https://doi.org/10.3763/ijas.2010.0583

Saha, B., \& Bahal, R. (2016). Livelihood diversification pursued by farmers in West Bengal. Indian Research Journal of Extension Education, 10(2), 1-9. 
Salayo, N. D., Perez, M. L., Garces, L. R., \& Pido, M. D. (2012). Mariculture development and livelihood diversification in the Philippines. Marine Policy, 36(4), 867-881. https://doi.org/10.1016/j.marpol.2011.12.003

Salvacion, A. R. (2019). Effect of climate on provincial-level banana yield in the Philippines. Information Processing in Agriculture. https://doi.org/10.1016/j.inpa.2019.05.005

Sobreviñas, A. B., \& Barrios, E. B. (2010). Impact of rice trade policy reforms on household welfare in the Philippines. Philippine Journal of Development, XXXVII, 1, 15-39.

Srisopaporn, S., Jourdain, D., Perret, S. R., \& Shivakoti, G. (2015). Adoption and continued participation in a public Good Agricultural Practices program: The case of rice farmers in the Central Plains of Thailand. Technological Forecasting and Social Change, 96, 242-253.

Stone, G. D., Netting, R. McC., \& Stone, M. P. (1990). Seasonality, labor scheduling, and agricultural intensification in the Nigerian savanna. American Anthropologist, 92(1), 7-23. https://doi.org/10.1525/aa.1990.92.1.02a00010

Strobl, E. (2019). The impact of typhoons on economic activity in the Philippines: Evidence from nightlight intensity. Asian Development Bank.

Suriya, A. C. N. P. (2016). Chapter 9-Coconut. In S. K. Gupta (Ed.), Breeding Oilseed Crops for Sustainable Production (pp. 201-216). Academic Press. https://doi.org/10.1016/B978-0-12-801309-0.00009-4 
Wadhwa, D. (2018, September 18). Understanding Poverty [Text/HTML]. World Bank. https://www.worldbank.org/en/understanding-poverty

Waha, K., Wijk, M. T. van, Fritz, S., See, L., Thornton, P. K., Wichern, J., \& Herrero, M. (2018). Agricultural diversification as an important strategy for achieving food security in Africa. Global Change Biology, 24(8), 33903400. https://doi.org/10.1111/gcb.14158

Wei, F., Wang, S., Fu, B., Zhang, L., Fu, C., \& Kanga, E. M. (2018). Balancing community livelihoods and biodiversity conservation of protected areas in East Africa. Current Opinion in Environmental Sustainability, 33, 26-33.

World Bank. (2019, October 11). The World Bank In East Asia Pacific: Overview [Text/HTML]. World Bank. https://www.worldbank.org/en/region/eap/overview

Zhang, W., Cao, G., Li, X., Zhang, H., Wang, C., Liu, Q., Chen, X., Cui, Z., Shen, J., \& Jiang, R. (2016). Closing yield gaps in China by empowering smallholder farmers. Nature, 537(7622), 671. 